
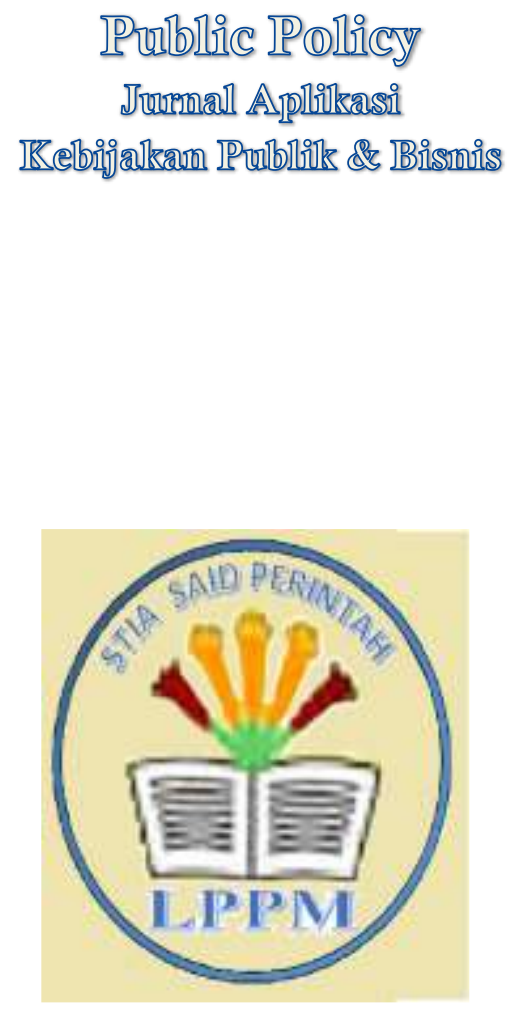

LPPM STIA Said Perintah

Volume 1, No. 2, September 2020

https://stia-saidperintah.e-journal.id/ppj

\section{Peran Pemerintah Daerah Dalam Mengontrol Harga Pangan Berdasarkan UU Pangan No. 18 Tahun 2012 Pasal 55 (Perspektif Ekonomi Islam)}

\author{
Murdiansah S. A. Karim \\ Universitas Bumi Hijrah Tidore \\ murdiansahsa@gmail.com
}

\section{Abstract}

The purpose of this research is to examine the role of local government, especially the city government of Tidore Islands, to stabilize food prices based on Food Law No. 18 of 2012 article 55 in the perspective of Islamic economics. This type of research is classified as qualitative research by presenting the direct relationship between the author and the respondent. In data collection techniques carried out include observation, interviews, and documentation, so that the authors conducted interviews with respondents including the Tidore City government and the tomato farmers of Gurabunga Village. In this study, the authors found that the role of regional government in managing food prices, local government not only controls one sector but the role of local government also controls the distribution of supply prices from farmers to the market without going through the collectors (middlemen).

Keywords : Price mechanism, Food Law, Distribution, Regional Intervention

\title{
Pendahuluan
}

Pasar merupakan salah satu aktifitas ekonomi, dalam pengertianya adalah mekanisme pertukaran barang dan jasa yang alamiah, hal tersebut berlangsung sejak awal peradaban manusia. Islam menempatkan pasar pada kedudukan yang paling tinggi dalam perekonomian. Pentingnya pasar tidak terlepas dari fungsi sebagai wadah bagi berlangsungnya jual beli. Sehingga secara ideal seseorang yang melakukan aktifitas ekonomi (bermuamalah) di pasar harus paham ketentuan dalam fikih muamalah (Fuad, 2016).

Ekonomi Islam memandang bahwa pasar, negara dan individu berada dalam keseimbangan (iqtishad), tidak boleh ada subordinat, sehingga salah satunya menjadi dominan dari yang lain. Pada konsep ekonomi Islam memberikan kebebasan di pasar. Bebas dalam menentukan produksi dan harga, tidak boleh ada gangguan yang 
mengakibatkan rusaknya keseimbangan pasar. Namun kenyataanya sulit ditemukan pasar yang berjalan sendiri secara adil (fair). Distorsi pasar tetap terjadi, sehingga dapat merugikan para pihak. (Agustiono, 2011)

Mekanisme pasar pada intinya adalah mekanisme harga, pada mekanisme harga ditentukan oleh permintaan (supply) dan penawaran (demand). Suatu permintaan dan penawaran adalah kekuatan yang saling terkait sehingga membentuk suatu komunitas pasar. Bila suatu permintaan terjadi secara alami dan normal, maka suatu kegiatan pasar akan berjalan stabil dan kondusif, tetapi sebaliknya bila pasar berjalan tidak normal dan penuh rekayasa, maka akan rusak (Fuad, 2016).

Fakta empiris yang terjadi para petani tomat kelurahan Gurabunga Kota Tidore kepulauan kesulitan mendapatkan harga pangan yang normal, hal tersebut terjadi kerena beberapa faktor diantaranya melimpah stok yang didatangkan dari luar Kota Tidore Kepulauan sehingga berpengaruh pada permintaan pasar, maka harga yang didapatkan kisaran Rp. 3000- Rp. 4000 per Kg, dan faktor distribusian hasil tomat ke pasar melalui para tengkulak atau pengumpul. Jika harga berkisaran Rp. 3000 per $\mathrm{Kg}$ produsen atau para petani akan mendapatkan keuntungan yang rendah (Portal Malut Post http://portal.malutpost.co.id).

Jika dilihat dari data pelaporan pelaksanaan kegiatan peningkatkan sistem dan jaringan informasi pasar di Kota Tidore Kepulauan harga mengalami penurunan di bulan September dan bulan Oktober. Pada bulan September minggu ketiga harga tomat normal Rp. 7000 rupiah tetapi mengalami penurunan minggu keempat diharga Rp. 4000 . Hal ini juga terjadi di bulan Oktober harga mengalami penurunan diharga Rp. 4000 rupiah. Perkembangan tanaman pangan khususnya pangan tomat di kelurahan Gurabunga sangat berpengaruh terhadap kesejahteraan petani, jika harga tomat tersebut pada kisaran Rp. 5000- Rp. 6000 rupiah per Kg. karena harga merupakan salah satu penentu keberhasilan suatu produsen untuk menentukan seberapa besar keuntungan akan diperoleh produsen dari penjual hasil produksinya baik berupa barang maupun jasa.

Sehingga dibutuhkan pemerintah Kota Tidore kepulauan untuk menstabilkan harga pangan tomat yang dapat dilakukan melalui kebijakan harga pangan agar mengurangi ketidakpastian petani dan menjamin harga pangan menjadi lebih stabil. Karena hal tersebut diatur dalam Undang-undang No. 18 Tahun 2012 tentang pangan (selanjutnya 
disingkat UU pangan) pasar 55 (ayat 1 dan 2) yaitu: Pertama, pemerintah berkewajiban melakukan stabilisasi pasokan dan harga pangan pokok ditingkat produsen dan konsumen. Kedua, stabilisasi pasokan harga pangan pokok dimaksud sebagaimana ayat (1) dilakukan untuk melindungi pendapatan dan daya beli petani nelayan, pembudi daya ikan, dan pelaku usaha mikro dan kecil serta menjaga keterjangkauan konsumen terhadap pangan pokok (UU No. 18 Tahun 2012).

UU Pangan bertujuan untuk melindungi produsen atau para petani dan konsumen agar terciptanya kesejahteraan. Sehingga peran pemerintah daerah sangat dibutuhkan dalam melakukan kebijakan. Poin pokok dari UU pangan adalah pemberian akses dan control yang besar kepada petani yang selama ini kurang diperhatikan, yaitu pemberian akses dan control terhadap lahan pertanian melalui hak penguasaan lahan melalui reformasi agrarian dan peningkatan akses. Disamping itu dibutuhkan kedaulatan pangan yang harus dicapai melalui lima usaha, yaitu peningkatan produksi pokok, stabilisasi harga pangan, peningkatan kesejahteraan pelaku usaha pangan. (Ilham dkk 2006)

Kebijakan intervensi di dapatkan juga dari hasil penelitian yang telah dilakukan Rahmawati (2016), (Rahmi, 2015), dan Amirah (2013) menyebutkan bahwa intervensi harga yang dilakukan pemerintah untuk melindungi pangan/para petani dan konsumen agar dapat membuat keseimbangan harga. Dalam konsep Islam intervensi dan regulotar dilihat juga pada penyebabnya, jika penyebabnya pada Genuine demand dan Genuine Supply maka dilakukan market Intervention. Sebaliknya jika peyebabnya distorsi Genuine demand dan Genuine suplly maka mekanisme pengendalian dengan price intervention (Rahmi, 2015).

Disinilah peran pemerintah dalam mekanisme pasar perlu mendapatkan perhatian utama tanpa mengorbankan potensi manusia dalam mengembangkan aktifitas ekonomi. Salah satu peran pemerintah dalam mengatur mekanisme pasar adalah menetapkan lembaga pengawas pasar (market supervision) keberadaan institusi ini sebagai regulator atau pengawas dalam proses mekanisme pasar terutama mengontrol harga dan para pelaku pasar (Fuad, 2016).

Pemaparan kajian empiris diatas termotivasi peneliti untuk meneliti peran pemrintahan daerah Kota Tidore kepualaun dalam hal mengontrol harga pangan yang sesuai dengan UU No 18 tahun 2012 yang bertujuan meninggkatkan kesejahteraan para 
petani dengan mengontrol harga, hal ini juga membedakan dengan peneliti terdahulu yang hanya melakukan studi permasalahan hanya pada harga tidak pada kebijakan UU pangan sehingga ada celah untuk peneliti melakukan penelitian tersebut dengan memasukan studi pada kebijakan UU Pangan No.18 Tahun 2012 dan mekaniseme harga pandangan ekonomi Islam.

Pada penelitian ini peneliti memilih 2 obyek penelitian yang pertama pada kelurahan Gurabunga sebagai penghasil tomat tiap mencapai 3-4 ton tomat. Hal ini membuat stok pada pasar Tidore mengalami kelebihan, sehingga menggakibtkan harga tomat para petani menurun. Obyek kedua pemerintahan Kota Tidore Kepulauan kerena pemerintah Kota Tidore sebagai pengawasan harga ketika mengalami penurunan, harga suatu barang mengalami penurunan bisa diakibatkan dari penawaran yang banyak tetapi permintaan di pasar menurun (Agustiono, 2011). Hasil penelitian ini diharapakan dapat memberikan kotribusi pada pemerintahan Kota Tidore Kepulauan dalam mengontrol harga pangan di Kota Tidore Kepulauan.

\section{Kajian Pustaka}

\section{Mekanisme Pasar dan Kebijakan Harga}

Pasar adalah sebuah mekanisme pertukaran produk baik berupa barang maupun jasa yang alamiah dan telah berlangsung sejak peradaban awal manusia. Islam menempatkan pasar pada kedudukan yang penting dalam perekonomian. Praktik ekonomi pada masa Rasulullah dan Khulafarasyidin menunjukan adanya peranan pasar yang besar dalam pembentukan masyarakat Islam pada masa itu. Rasulullah SAW., sangat menghargai harga yang dibentuk oleh mekanisme pasar sebagai harga yang adil. Bilau menolak adanya suatu intervensi harga (price intervention) seandainya perubahan harga terjadi kerena mekanisme pasar yang wajar, yaitu hanya kerena pergeseran permintaan dan penawaran. Namun pasar disini mengahruskan adanya moralitas dalam aktivitas ekonominya, antara lain persaingan sehat dan adil (fair play) kejujuran (honesty), keterbukaan (transparency), dan keadilan (justice) jika nilai-nilai ini di tegakan maka tidak ada alasan dalam ekonomi Islam untuk menolak harga yang berbentuk oleh mekanisme pasar (Al-Arif, 2010). 
Dalam konsep ekonomi Islam penentuan harga dilakukan oleh kekuatan-kekuatan pasar, yaitu kekuatan permintaan dan kekuatan penawaran. Dalam konsep Islam, pertemuan permintaan dengan penawaran tersbut haruslah terjadi secara rela sama rela, tidak ada pihak yang merasa terpaksa untuk melakukan transaksi pada tingkat harga tersebut. Keadaan rela sama rela merupakan kebalikan dari keadaan aniaya, yaitu keadaan dimana salah satu pihak senang diatas kesedihan orang lain. Dalam harga, para ahli fiqh merumuskannya sebagai the price of equivalent. Konsep the price of the equivalent ini mempunyai implikasi penting dalam ilmu ekonomi, yaitu keadaan pasar yang kompetitif (Karim, 2011).

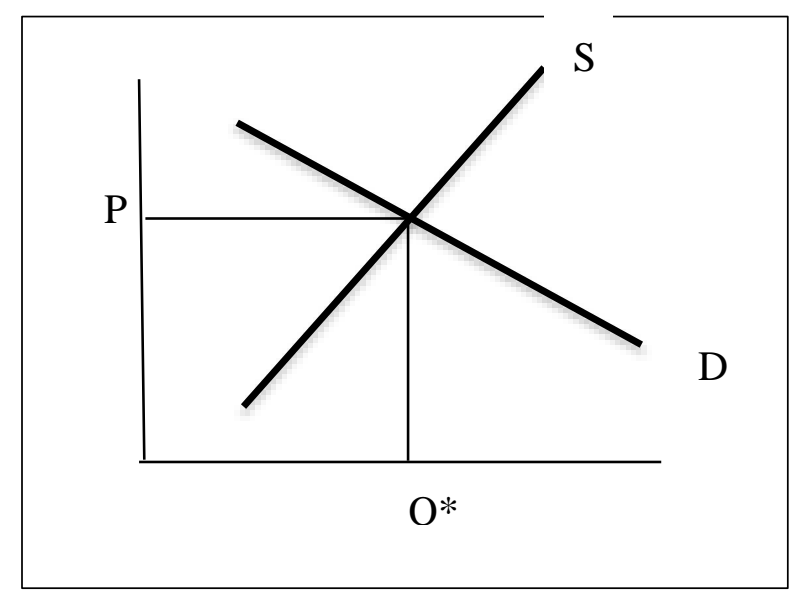

Gambar Keseimbangan Pasar

Sumber: Buku Ekonomi Mikro Islam (Karim, 2011).

Keterangan: Keseimbangan pasar terjadi pada saat perpotongan antara kurva supply dan demand dalam keadaan "an taraddim minkum" (rela sama rela). Bila ada yang menganggu keseimbangan ini, maka pemerintah harus melakukan intervensi pasar.

Dalam konsep Islam, monopoly, duopoly, oligopoly dalam artian hanya ada satu, dua penjual atau beberapa penjual tidak dilarang keberadaannya, selama mereka tidak mengambil keuntungan diatas keuntungan normal. Ini merupkan konsekuensi dari konsep the price of the equivalent. Produsen yang beroperasi dengan positif Profit akan mengandung produsen lain untuk masuk kedalam bisnis tersebut, sehingga kurva supply bergeser ke kanan, jumlah output yang ditawarkan bertambah dan harga akan turun. 
Produsen baru akan memasuki bisnis tersebut sampai dengan harga turun sedemikian sehingga economic profit nihil. Pada keadaan ini produsen telah ada di pasar tidak mempunyai insentif untuk keluar dari pasar, dan produsen yang belum masuk ke pasar tidak mempunyai insentif untuk memasuki ke pasar (Robert Pindyck dan Daniel Rubinfled, 1995).

\section{Peran Pemerintah dalam Mengontrol Harga}

Untuk lebih menjamin berjalannya mekanisme pasar secara sempirna perenan pemerintah sengat penting. Rsulullah Saw., sendiri telah menjalankan fungsi sebagai market supervisor atau Al-Hisbah, yang kemudian banyak dijadikan acuan untuk peran negara terhadap pasar. Menurut Al-Mawardi, eksistensi dalam peranan al-Hisbah berangkat dari firman Allah yang artinya, "dan hendaklah di antara kamu ada segolongan umat yang menyuruh kepada kebaikan, menyuruh kepada yang ma'ruf, dan mencegah dari munkar: merekalah orang-orang yang beruntung." Sementara dalam bukunya Al-Hisbah fi'I Islam, Ibn Taimiyah banyak mengungkap tentang peranan Al-Hisbah pada masa Rasulullah Saw. Rasulullah Saw. sering melakukan inspeksi ke pasar untuk mengecek harga dan mekanisme pasar. Seringkali dalm inpeksinya beliau menegurnya. Rasulullah Saw. juga telah memberikan banyak pendapat, perintah maupun larangan demi sebuah pasar yang Islami. Semua ini mengindikasikan sevata jelas bahwa AL-Hisbah telah ada sejak masa Rasululllah Saw., meskipun nama Al-hisbah baru datang di masa kemudian (P3EI, 2014).

Muhammmad Al-Mubarak, (1973) menyatakan bahwa Al-Hisbah merupakan fungsi kontrol dari pemerintah melalui kegiatan perorangan yang khususnya memeliki garapan di bidang moral, agama dari ekonomi, dan secara umum berkaitan dengan kegiatan kolektif atau publik untuk mencapai keadilan dan kebenaran menurut prinsip Islam dan dikembangkan menjadi kebiasaan umum paa waktu dan tempat. Ziadeh mendefinisikan ALHisbah sebagi sebuah lembaga yang berfunsi untuk mengontrol pasar dan moral secara umum atau adab (P3EI, 2014).

Al-Hisbah tetap banyak didirikan sepanjang bagian terbesar dunia Islam, bahkan di beberapa negara insttitusi ini tetap bertahan hingga awal abad ke-20 M. selama periode dinasti mamluk AL-Hisbah memlliki peranan penting. Terbukti dengan sejumlah kemajuan ekonomi yang dicapai pasa masa itu. Di Mesir, Al-Hisbah tetap bertahan sampai pada masa pemerintah Muhammad Ali (1805-1849). Bahkan, di Maroko hingga awal abad ke-20, institusi ini masih dapat dijumpai. Hal yang sama juga terjadi di Romawi Timur, yang telah 
melakukan kontrak dengan dunia Islam melalui perang salib, lembaga serupa juga diadopsi, adopsi lembaga ini tampak jelas dengan nama yang mirip, yaitu Mathessep yang kemungkinan berasal dari kata muthasib.

Pada pemikiran ekonomi Islam kontemporer, eksistensi Al-Hisab sering kali dijadikan acuan bagi fungsi negara terhadap perekonomian, khususnya dalam pasar. Namun, elaborsi Al-Hisbah dalam kebijakan praktis ternyata terdapat bentuk. Beberapa ekonomi berpendapat bahwa AL-hisbah akan diperankan oleh negara secara umum melalui berbagai institusinya. Jadi, Al-hHisbah melekat pada fungsi negara dalalm pada dan tidak perlu membentuk lembaga khususnya. Sementara itu, sebgaian lainnya berpendapat perlu dibentuk lembaga khusus yang diberi nama Al-Hisbah ini, jadi, Al-Hisbah adalah semacam polisi khusus ekonomi. Bahkan lembaga ini merupakan suatu agen independen sehingga terlepas dari kepentingan kelompok tertentu atau pemerintah itu sendiri. Namun, dengan melihat fungsi Al-Hisbah yang luas dan kurang realitas. Fungsi al-Hisbah akan melekat pada fungsi pemerintah secara keseluruhan, dimana dalam teknis operasionalnya akan dijalankan oleh kementerian, depertemen, dinas atau lembaga lain yang terkait (P3EI, 2014).

\section{Metode Penelitian}

Penelitian ini menjelaskan secara langsung hakikat hubungan antara responden dengan penulis terhadap pengaruh yang dihadapi. Pendektan penelitian ini mengunakan metode kualitatif. Metode penelitiannya adalah model survei dan mewancari beberapa reponden. Penelitian ini mewancarai responden diantara para petani tomat yang berada pada kelurahan Gurabunga, Pemerintah Kota Tidore Kepulauan yang diwawancari bapak Wali Kota Tidore Ali Ibrahim., SE, dan Ketua Bina Pasar Dinas Perindakop. Analisis data yang digunakan penelitian ini diantaranya reduksi, Triangulasi data dan kesimpulan. Reduksi data merupakan bentuk analisis yang menajamkan, menggolongkan, mengarahkan, memilah yang tidak perlu dianalisis dan mengorganisasi data sehingga bisa ditarik kesimpulan dan di verifikasi. Pada penelitian ini juga menggunakan Triangulasi untuk mengecek kebenaran data juga dilakukan memperkrya data. Dari hasi metode yang di analisiskan baru ditarik kesimpulan dari kebenaran metode yang dianalisiskan. 


\section{Hasil dan Pembahasan}

Peran Pemerintah Daerah Dalam Mengontrol Harga Pangan Berdasarkan UU No. 18 Tahun 2012 Pasal 55 di Kota Tidore Perspektif Ekonomi Islam

Provinsi Maluku Utara Khususnya Kota Tidore Kepulauan merupakan daerah penghasil tomat, tiap tahunnya para petani Kota Tidore Kepulauan menghasilkan tomat mencapai 14 ton. Hal tersebut bertujuan untuk pembangunan pulau mandiri yang bisa menghasilkan produksi pangan tomat. Karena kemandirian pangan secara nasional tidak dapat terwujud tanpa adanya kemandirian di pulau-pulau kecil. Etika dan pembangunan kecil harus diikuti dalam membangun ekonomi pulau-pulau kecil termasuk pembangunan produksi.

Dalam menganalisis penelitian mengenai peranan pemerintah dalam mengelola harga pangan berdasarkan UU No. 18 Tahun 2012 pasal 55, penulis menggunakan beberapa aspek diantaranya mengenai pasokan produksi pangan, harga pangan dan intervensi pemerintah dalam mengelola harga pangan, hal tersebut agar analisisnya lebih mengarah dan sesuai dengan fokus penelitian mengenai harga pangan.

Harga pangan menjadi salah satu faktor penting dalam perkembangan perekonomian saat ini, sehingga kebijakan pangan di atur dalam UU No. 18 Tahun 2012, pengertian pangan menurut UU pangan merupakan sesuatu yang berasal dari sumber hayati produk pertanian, perkebunan, kehutanan, perikanan, perternakan, perairan, dan air, baik yang diolah maupun yang tidak diolah yang diperuntukan sebagai makanan atau minuman bagi konsumsi manusia, termasuk bahan tambahan pangan, bahan baku pangan, dan bahan lainnya yang digunakan dalam proses penyiapan, pengolahan, dan/atau pembuatan makanan atau minuman.

Pada UU No. 18 Tahun 2012 ini tidak hanya mengatur mengenai pasokan, stabilisasi harga tetapi mengatur mengenai kemandirian dalam memproduksi pangan yang ada di kota-kota kecil. Sehingga dalam penelitian ini penulis hanya memfokuskan pada pasal 55 mengenai stabilisasi harga pangan dan pasokan pangan yang dikelola oleh pemerintah daerah khususnya pemerintah Kota Tidore Kepulauan. Dalam pasal 55 ayat 1 sudah diataur bahawa pemerintah berkewajiban melakukan stabilisasi pasokan dan harga pada tingkat produsen dan konsumen. Sehingga pasokan pangan dan harga pangan merupakan dua aspek permasalahan. 


\section{Pasokan Pangan}

Produksi pangan merupakan penentuan dari pengaruh harga komoditas pertanian. Semakin banyak produksi komoditas pertanian, semakin banyak jumlah komoditas yang dihasilkan, tetapi bila produksi sedikit maka jumlah komoditas pertanian yang akan dihasilkan akan sedikit dan itu akan berpengaruh pada harga komoditas pertanian yang ada, sehingga akan menyebabkan harga komoditas pertanian akan naik dengan tajam. Dengan artian bahwa jika produksi komoditas pertanian sedikit, akan menyebabkan harga komoditas pertanian akan naik.

Pasokan (penawaran) dalam mekanisme pasar merupakan kekuatan penting, hukum penawaran berbanding lurus antara harga terhadap jumlah barang yang ditawarkan, yaitu apabila harga meningkat, maka penawaran akan meningkat, sebaliknya jika harga turun, maka penawaran turun (Muhammad, 2005).

Permasalahan yang terjadi di Kota Tidore Kepulauan yaitu kelebihan pasokan pangan tomat. Jika dilihat data informasi harga pasar hal ini terjadi di bulan Oktober, pada bulan ini rata-rata kelurahan di Kota Tidore Kepulauan memproduksi hasil tomat mencapai 200-500 kg dan kelurahan Gurabunga sendiri mencapai 2-3 ton tomat, sedangkan pasar di Kota Tidore hanya bisa menapung 1 ton tomat. Sehingga hal tersebut menyebabkan kelebihan pasokan tomat.

Pada permasalahan diatas dapat penulis analisiskan bahwa di Tidore Kepulauan pasokan pangan lokal sangat memenuhi pasar. Jika dilihat dari hasil wawancara ratarata kelurahan di Tidore memproduksi pangan tomat, dengan banyak pasokan komoditi lokal maka pasaran akan mengalami kelebihan penawaran. Jika terdapat kebelihan pasokan akan membuat harga mengalami penurunan. Kelebihanya karena tiap bulan kelurahan di Kota Tidore Kepulauan mengahasilkan produksi pangan tomat sebesar 200$500 \mathrm{~kg}$, dan untuk kelurahan Gurabunga tiap bulanya mencapai 2-3 ton tomat dan termasuk kelurahan yang menghasilkan produksi tomat yang paling banyak, tetapi pasaran di Kota Tidore hanya bisa menampung 1 ton pangan tomat.

Sehingga pasokan komoditi tomat di pasar harus diatur agar harga komoditi lebih stabil, jika pasar terdapat penawaran yang relatif sangat banyak, maka barang tersedia di pasar dapat memenuhi semua permintaan, dan mempercepat penjualan karena produsen menurunkan harga jual produk tersebut. Maka dari itu peran pemerintah Kota 
Tidore mengatur pasokan pangan lokal dan mengontrol pasokan komoditi tomat yang datang dari luar Kota Tidore, sehingga pasokan komoditi yang dijual di pasar relatif seimbang.

Dalam kebijakan strategis pemerintah daerah memastikan pencapaian tujuan dan sasaran, tujuannya adalah mengendalikan stabilitas harga, pasokan dan distribusi barang kebutuhan pokok. Dalam kebijakan tersebut sesuai dengan UU pangan No. 18 Tahun 2012 pasal 55 ayat 1 dan 2 yang berbunyi: Pertama: pemerintah berkewajiban melakukan stabilisasi pasokan dan harga pangan pokok ditingkat konsumen. Kedua: Stabilisasi pasokan dan harga pangan pokok sebagaimana dimaksud pada ayat (1) dilakukan untuk melindungi pendapatan dan daya beli petani, Nelayan, Pembudi daya ikan, dan pelaku usaha mikro dan kecil serta menjaga keterjangkauan konsumen terhadap pangan pokok (Republik Indonesia, 2012).

Kebijakan pemerintah merupakan salah satu peran intervensi untuk mengontrol pasokan komoditi pangan yang ada di Kota Tidore Kepulauan. Dalam kebijakan pemerintah daerah adalah dengan menghentikan pasokan yang didatangkan dari luar Kota Tidore kepalauan, pasokan komoditi yang sering didatangkan dari Manado, Sulawesi dan Surabaya. Jika hal tersbut tidak dilakukan maka akan terjadi kelebihan pasokan, karena pasokan pangan tomat lokal sudah memenuhi pasar di Kota Tidore kepulauan (Portal Malut Post - http://portal.malutpost.co.id).

2. Harga Pangan

Dalam pandangan konsep Islam mengenai intervensi pasar adalah ketika pengendalian harga ditentukan penyebabnya. Hal ini dilakukan karena perubahan pada permintaan dan penawaran, maka mekanisme pengendalian melalui intervensi pasar. Sedangkan bila penyebabnya dilakukan distorsi terhadap permintaan dan penawaran, maka mekanisme pengendalian dilakukan melalui penghilangan distorsi terhadap penentuan harga untuk mengendalilkan harga pada keadaan sebelum distorsi (Heri, 2002).

Pengawasan harga pada ekonomi Islam bersifat pengawasan komprehensif untuk memastikan semua penjual atau perniagaan mengikuti perniagaan secara Islam. Dengan demikian jelaslah bahwa konteks harga, peranan bersifat sementara. Dijelaskan 
bahwa pemerintah mengintervensi harga jika terjadi kezaliman atau kecurangan berlaku di pasaran. Jika tidak harga pasar akan menentukannya (Syahpawi, 2013).

Mengenai hal ini salah satu pemikir ekonomi Islam Ibnu Taimiyah membolehkan intervensi harga guna terjadi kesetaraan dalam pasar (dhaman al-mithl) pada keadaan tertentu, sepintas pendapatnya bertentangan dengan sikap Rasulullah yang menolak intervensi harga. Intervensi harga yang zalim dan adil menurut Ibnu Taimiyah diantaranya, intervensi harga yang zalim yaitu suatu intervensi yang dianggap bila terjadi harga maksimum (ceiling price) ditetapkan dibawah harga keseimbangan yang terjadi melalui mekanisme pasar yaitu atas dasar rela sama rela. Secara paralel dapat pula dikatakan bahwa harga minimum yang ditetapkan diatas harga keseimbangan kompetitif adalah zalim. Sedangkan untuk intervensi harga yang adil yaitu suatu intervensi dianggap adil sepanjang tidak menimbulkan kerugian di salah satu pihak antara penjual dan pembeli (Syahpawi, 2013).

Pada mekanisme pasar pasokan pangan tomat sangat mempengaruhi harga pangan salah satunya pangan tomat yang ada di Tidore Kepaulauan. Jika dilihat dari data 3 bulan terakhir pada tahun 2017 harga di pasar Kota Tidore Kepulauan mengalami fluktuasi harga. Pada bulan oktober untuk minggu terakhir di bulan sebelumnya di angka Rp. 8.000 rupiah. Untuk meihat kenaikan dan penurunan harga harus ada pembanding pada minggu terakhir bulan sebelumnya atau bulan september. Sedangkan harga minggu pertama di bulan oktober mengalami penurunan Rp. 7.000 rupiah, harga tersebut turun Rp. 1.000 rupiah. Minggu-minggu selanjutnya harga mulai stabil tetapi pada minggu terakhir harga turun sangat rendah di harga Rp. 4.000 rupiah (Data Informasi Harga Kebutuhan Pokok dan Pangan Tahun 2017).

Bulan November harga mengalami kenaikan dari harga Rp. 4.000 rupiah menjadi Rp. 5.000 rupiah. Harga ini mengalami peningkatan Rp. 1.000 rupiah. Pada bulan ini harga mengalami peningkatan tiap minggunya, sampai pada minggu terakhir harga menjadi Rp. 8.000 rupiah rupiah. Sedangkan di bulan Desember harga pangan tomat tetap stabil di harga Rp. 8.000 rupiah, tetapi untuk minggu terakhir mulai meningkat Rp. 2.000 rupiah menjadi harga Rp. 10.000 rupiah (Data Informasi Harga Kebutuhan Pokok dan Pangan 2017). 
Harga pangan tomat di Kota Tidore mengalami penurunan disebabkan karena kelebihan pasokan yang tidak bisa ditampung oleh pasar di Tidore, kelebihan ini disebabkan produksi pangan lokal dari beberapa kelurahan yang memproduksi pangan tomat tersebut. Dari data yang didapat tiap minggunya para petani menghasilkan panen tomat mencapai 2-3 ton sedangkan pasar hanya bisa menampung hasil panen tomat 1 ton, sehingga menyebabkan harga di Tidore mengalami penurunan. Jika dibandingkan dengan harga lokal seluruh Maluku Utara harga di Tidore sangatlah menurun di angka Rp. 4000 rupiah. Ketika harga tomat ini turun para petani yang memproduksi tomat akan mendapatkan keuntungan yang kecil. Para produksi atau petani tomat mendapatkan keuntungan di harga Rp. 5.000 rupiah per $\mathrm{Kg}$, sedangkan harga turun di bawah Rp. 5.000 maka para petani mendapatkan keuntungan yang kecil.

Menganai hal ini dapat dianalisiskan bahwa keuntungan tersebut didapat bukan dari hasil jual panen langsung ke pasar tetapi harga hasil panen tersebut didapat dari para pengumpul atau biasanya para petani tomat Gurabunga menyebutnya para dibodibo (tengkulak). Kebanyakan para petani tomat di kelurahan Gurabunga menjual hasil panennya ke para pengumpul, harga tomat yang di jual ke pengumpul berbeda dengan harga yang ada di pasar. Petani menjual ke pengumpul di bawah harga pasar dengan harga antara Rp 5.000- Rp. 6.000 rupiah sedangkan para pengumpul (tengkulak) menjual diatas harga tersebut. Sehingga keuntungan antara para petani dengan pengumpul sangat besar, selisihnya di harga Rp. 2.000 rupiah.

Dalam teori eknomi Islam keuntungan merupakan salah satu faktor dari penawaran (pasokan). Ibn Taimiyah mengistilahkan penawaran sebagai ketersedian barang. Pandanganya tentang penawaran tersebut berasal dari impor dan produksi lokal sehingga kegiatan dilakukan oleh produsen maupun penjual (P3EI, 2014). Keuntungan merupakan salah satu bagian dari mashlahah kerena ia dapat mengakumulasi modal yang pada akhirnya dapat digunakan untuk berbagai aktifitas. Dengan kata lain, keuntungan akan menjadi tambahan modal guna memperoleh mashlahah lebih besar untuk mencapai falah (Farida, 2012).

Hal ini maka ada kesenjangan kekayaan antara para petani dengan para pengumpul, permasalahan yang terjadi ialah tidak ada wadah untuk pengelolaan hasil panen tomat para petani untuk didistribusian langsung ke pasar. Disamping itu ada 
Selisih harga antara para petani dengan tengkulak di harga Rp. 2.000 rupiah. Oleh karena itu, dalam sistem Islam mengarahkan kepada distribusi yang adil sehingga komunitas para petani tidak ada jenjang level kekayaan yang terpaut berjauhan antara satu dengan lainnya. Distirbusi pendapatan atau pembagian kekayaan akan menjamin terjadinya keadilan distribusi barang dan jasa di pasar. Dalam persaingan pasar sempurna dan pasar terbuka setiap individu akan selalu berfikir dan berusaha untuk mendapatkan manfaat atau utilitas tertinggi dari setiap cadangan pengeluarannya (Nasution, 2012). Hal ini serta merta akan merusak mekanisme pasar, Ibnu Taimiyah mengatakan bahwa: "penjual dilarang apabila degan sengaja tidak menjual sesuatu kecuali dengan harga bisa ditentukan sendiri.

Dalam firman Allah SWT surat An-Nisa ayat 29 yang berbunyi:

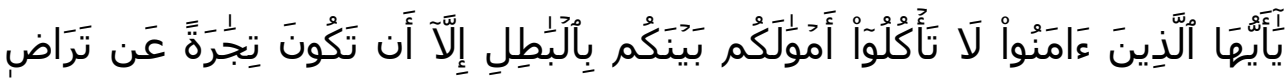

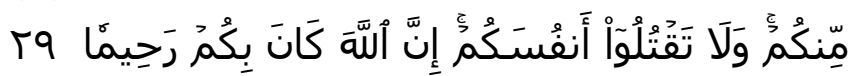

Artinya

"Hai orang-orang yang beriman, janganlah kamu saling memakan harta sesamamu dengan jalan yang batil, kecuali dengan jalan perniagaan yang Berlaku dengan suka sama-suka di antara kamu. dan janganlah kamu membunuh dirimu" (Kementrian Agama Republik Indonesia, 2014).

Sehingga harga yang adil antara para petani dengan pasar agar tidak lagi ada kesenjangan atau level kekayaan yang terpaut jauh atau tidak kedazaliman. Dalam transaksi Islam harga adil merupakan prinsip bisnis. Harga yang adil adalah harga yang tidak menimbulkan eksploitas atau penindasan (kedazaliman) sehingga menimbulkan kerugian disalah satu pihak dan menguntungkan pihak lain. Harga harus mencerminkan manfaat bagi pembeli dan penjualnya secara adil, yaitu penjual memperoleh keuntungan yang normal dan pembeli mendapatkan manfaat yang setara sesuai dengan harga yang dibayarkan (P3EI, 2014). Dalam hal ini maka harga antara petani dengan para pembeli harus setara atau sesuai dengan harga pasar. Oleh karena itu dibutuhkan intervensi pemerintah daerah untuk membuat regulasi harga yang setara.

Dalam regulasi pemerintah daerah khususnya pemerintah daerah Kota Tidore Kepulauan tidak hanya mengontrol pasokan tomat tetapi juga mengontorl harga, mengontrol pasokan yaitu pemerintah melakukan pengontrol pasokan yang ditimbun 
atau mengurangi produksi yang sekedar kolusi. Jika hal ini terjadi maka ada permainan atau kelompok-kelompok tertentu yang mengandalikan harga untuk kepentingan mereka. Oleh karena itu, pemerintah daerah sebagai muhtasib berkewajiban untuk memberi ukuran-ukuran yang benar. Salah satu fungsi pemerintah daerah adalah menegakan keadilan di masyarakat.

3. Peran Pemerintah Daerah

Dalam mengontrol pasokan dan harga pangan tomat maka dibutuhkan regulasi dari pemerintah daerah agar pasokan dan harga tetap stabil, regulasi ini bertujuan untuk memelihara kejujuran dan kemungkinan penduduk untuk memenuhi kebutuhan pokoknya (Chamid, 2010). Sehingga kebijakan yang dilakukan pemerintah Kota Tidore Kepualaun yaitu mengawasi dan mengontrol harga pangan tomat.

Pemerintah daerah Kota Tidore melakukan pengawasan dan pengontrolan harga baik itu barang pokok maupun barang penting. Dalam hal ini pemerintah daerah Kota Tidore Kepulauan mengawasi dan memastikan kelangsungan produksi dan kestabilan suplai barang-branag pokok masyarakat. Untuk mencapai skala produksi yang efektif dan kelancaran aliran suplai barang dan jasa. Disamping itu pemerintah sebagai hisbah juga melakuakn fungsi alokasi sumber daya, penyedian kebutuhan pokok, menjamin kebebasan keluar masuk pasar, memastikan tidak adanya intersepsi pasar, memperlancar akomodasi bagi suplier perdesaan, menetapkan perantara, pencegahan terjadinya distorsi pasar dan memastikan tidak adanya kecurangan (Kusnawati,2015)

Menurut Ibnu Qudamah dalam jurnal mekanisme pasar dalam Islam mengatakan bahwa tujuan intervensi pasar yang dilakukan pemerintah yaitu intervensi harga yang menyangkut kepentingan masyarakat, untuk mencegah ikhtikar dan ghaban faa-hisy (mengambil keuntungan diatas keuntungan normal dan menjual diatas harga pasar), dan untuk melindungi kepentingan masyrakat yang lebih luar (Rahmi, 2015).

Adapun regulasi harga yang merupakan bagian dari intervensi pemerintah memiliki 3 fungsi, yaitu fungsi ekonomi yang merupakan berhubungan dengan peningkatan produkstivitas dan peningkatan pendapatan masyarakat miskin melalui alokasi dan relokasi sumber daya ekonomi, fungsi sosial adalah mempersempit kesenjangan antara masyarakat kaya dan masyarakat miskin dan fungsi moral adalah upaya menegakkan nilai-nilai Islami dalam aktifitas perekonomian (Rahmi, 2015). 
Intervensi pemerintah dalam pasar bukan hanya bersifat sementara, tetapi ia akan mengambil peranan yang besar dan penting. Pemerintah bukan hanya sekedar memantau pasar, tetapi pemerintah berperan aktif bersama pelaku- pelaku pasar yang lain. Pemerintah dapat bertindak sebagai perencana, pengawas, pengatur, produsen sekaligus konsumen bagi kegiatan pasar (Hakim, 2015).

Hal ini mengaju pada UU Pangan No. 18 Tahun 2012 pasal 55 dimana pada ayat Pertama berbunyi: pemerintah berkewajiban melakukan stabilisasi pasokan dan harga pangan pokok di tingkat produsen dan konsumen, Kedua stabilisasi pasokan dan harga pangan pokok sebagai dimaksud pada ayat (1) dilakukan untuk melindungi pendapatan dan daya beli petani, nelayan, pembudi daya ikan, dan pelaku usaha mikro kecil, serta menjaga keterjangkauan konsumen terhadap pangan pokok (Republik Indonesia, 2012).

\section{Penutup}

\section{Simpulan}

Dari permasalahan diatas maka penulis menarik kesimpulan bahwa peran yang dilakukan pemerintah daerah khususnya pemerintah Kota Tidore Kepulauan pada pengontrolan harga di pasar dan pengontrolan ketersedian, tetapi pemerintah daerah tidak mengontrol harga pasokan pendistribusian hasil panen para petani yang dijual di pasar. Oleh karena itu, dibutuhkan peran pemerintah daerah untuk mengontrol pendistribusian harga pangan tomat yang akan dijual ke pasar. Sehingga harga pangan tomat tetap normal antara para petani dengan pasar. Mengenai hal tersebut konsep ekonomi Islam memperbolehkan adanya intervensi pemerintah untuk melakukan pengaturan, penetapan dan pengawasan harga. Sehingga harga pangan tetap stabil dan sesuai dengan UU Pangan No. 18 Tahun 2012 pasal 55 yang kebijakan mengatur kestabilan harga pada konsumen dan melindungi pendapatan para petani.

\section{Daftar Pustaka}

Al-Arif, M. N. R. (2010). Dasar - Dasar Ekonomi Islam. Solo: PT Era Adicitra Intermedia.

Chamid, N. (2010). Jejak Langkah Sejarah Pemikiran Ekonomi Islam. Yogyakarta: Pustaka Pelajar. 
Farida, U. J. (2012). Telaah Kritis Pemikiran Ekonomi Islam Terhadap Mekanisme Pasar Dalam Konteks Ekonomi Islam Kekinian. La_Riba, 6(2), 257-270. https://doi.org/10.20885/lariba.vol6.iss2.art7

Fuad. (2016). Pengawan Pasar dalam Islam (Studi Pemikir Ibnu Taimiyah Tentang Hisbah). Hakim, M. A. (2015). Peran Pemerintah Dalam Mengawasi Mekanisme Pasar Dalam Perspektif Ekonomi Islam. Iqtishadia, $8(1), \quad 19-40$. https://doi.org/10.32678/alqalam.v28i3.889

Karim, A. A. (2011). Ekonomi Mikro Islam. PT Raja Grafindo Persada.

Muhammad. (2005). Ekonomi Mikro Dalam Perspektif Islam. Yogyakarta: BPFE-Yogyakarta. Nasution, M. E. (2012). Pengenalan Ekslusif Ekonomi Islam. Jakarta: Kencana.

P3EI. (2014). Ekonomi Islam (6th ed.). Jakarta: Raja Grafindo Persada.

Rahmi, A. (2015). Mekanisme Pasar dalam Islam. Jurnal Ekonomi Bisnis Dan Kewirausahaan, 4(2), 177-192. https://doi.org/10.26418/jebik.v4i2.12481

Republik Indonesia. Undang Undang Pangan. , (2012).

Sudarsono Heri. (2002). Konsep Ekonomi Islam. Yogyakarta: Ekonisia.

Syahpawi. (2013). Price Intervention Terhadap Kesetaraan Harga (Thaman Al-Mithl) Perspektif Barat Dan Islam. Hukum Islam, 13(1), 120-136. 